\title{
FAKTOR-FAKTOR YANG MEMPENGARUHI TINGKAT KEPUASAN KARYAWAN DALAM MENGGUNAKAN UANG ELEKTRONIK KARTU FLAZZ BCA DI LINGKUNGAN ANANTARA SEMINYAK RESORT - BALI
}

\author{
Oleh \\ Komang Aditya Satya Diptha, NIM.1214011067 \\ Program Studi Pendidikan Ekonomi, Fakultas Ekonomi \\ Universitas Pendidikan Ganesha \\ Singaraja, Indonesia \\ e-mail: adityasatya18km@gmail.com
}

\begin{abstract}
ABSTRAK
Penelitian ini bertujuan untuk mengetahui, (1) faktor-faktor yang mempengaruhi tingkat kepuasan karyawan dalam menggunakan uang elektronik kartu Flazz BCA di lingkungan Anantara Seminyak Resort-Bali, (2) faktor yang paling dominan mempengaruhi tingkat kepuasan karyawan dalam menggunakan uang elektronik kartu Flazz BCA di lingkungan Anantara Seminyak Resort - Bali. Jenis penelitian ini merupakan penelitian kuantitatif. Menggunakan kuesioner sebagai metode pengumpulan data dan menggunakan teknik analisis faktor sebagai teknik ananlisis data. Hasil penelitian menunjukkan, (1) tingkat kepuasan karyawan dalam menggunakan uang elektronik kartu Flazz BCA di lingkungan Anantara Seminyak Resort - Bali, yaitu kemudahan, manfaat, risiko, kepercayaan, dan kualitas produk. Besarnya variance explained faktor secara berturut-turut, yaitu kemudahan sebesar $35,501 \%$, manfaat sebesar $24,711 \%$, risiko sebesar $15,935 \%$, kepercayaan sebesar $14,897 \%$, dan kualitas produk sebesar $9,456 \%$, (2) faktor yang paling dominan mempengaruhi tingkat kepuasan karyawan dalam menggunakan uang elektronik kartu Flazz BCA di lingkungan Anantara Seminyak Resort - Bali, yaitu kemudahan dengan memiliki variance explained sebesar $35,501 \%$, artinya total nilai variance explained dari kemudahan menggunakan mampu menjelaskan tingkat kepuasan karyawan dalam menggunakan uang elektronik kartu Flazz BCA di lingkungan Anantara Seminyak Resort - Bali.
\end{abstract}

Kata kunci: kepuasan, uang elektronik, kartu Flazz BCA

\section{ABSTRACT}

This study aims to determine (1) the factors that affect the level of employee satisfaction in using electronic money Flazz card BCA in the Anantara Seminyak Resort - Bali and (2) the most dominant factors affecting the level of employee satisfaction in using electronic money Flazz card BCA environmental Anantara Seminyak Resort - Bali. This type of research is quantitative research and using factor analysis as data analysis techniques. Results showed that (1) the level of employee satisfaction in using electronic money Flazz cards BCA in the Anantara Seminyak Resort - Bali, namely convenience, benefits, risks, trust, and quality of products. The amount of variance explained by factors respectively, the ease of $35.501 \%, 24.711 \%$ of the benefits, risks amounted to $15.935 \%, 14.897 \%$ of the trust, and product quality at $9.456 \%$. (2) the most dominant factors affecting the level of employee satisfaction in using electronic money Flazz card BCA in the Anantara Seminyak Resort - Bali, the ease with having variance explained by $35.501 \%$, meaning that the total variance explained of the ease of use is able to explain the level of employee satisfaction in using electronic money Flazz cards BCA in the Anantara Seminyak Resort - Bali.

Keywords : satisfaction, electronic money, card Flazz BCA 


\section{PENDAHULUAN}

Di era modern sekarang, peranan perbankan dalam memajukan perekonomian suatu negara sangatlah besar. Hampir semua sektor yang berhubungan dengan berbagai kegiatan keuangan selalu membutuhkan jasa bank. Oleh karena itu, saat ini dan dimasa yang akan datang jika hendak menjalankan aktivitas keuangan, baik perorangan maupun lembaga, baik sosial atau perusahaan kita tidak akan terlepas dari dunia perbankan (Kasmir, 2000).

Perbankan dituntut sebagai wahana yang mampu untuk berkembang sesuai dengan perkembangan teknologi informasi saat ini. Fungsi dari perbankan tidak hanya mampu menghimpun dan menyalurkan dana kepada masyarakat secara efektif dan efisien tetapi juga menyediakan jasa ataupun pelayanan. Setiap tahapan proses penyediaan jasa atau pelayanan jasa harus berorientasi pada kualitas. Secara garis besar kualitas orientasinya adalah kepuasan pelanggan atau kepuasan nasabah yang merupakan tujuan perusahaan maupun perbankan (M. Nur Rianto al Arif, 2010).

Kepuasan pengguna dapat ditunjukkan melalui sikap pengguna setelah menggunakan produk yang didapatkan. Kepuasan pengguna akan terlihat dari seberapa baik produk yang didapatkan dan dirasakan. Semakin baik kualitas produk yang didapatkan, maka kepuasan pengguna akan semakin baik. Kotler (2000) mendefinisikan kepuasan sebagai perasaan senang atau kecewa seseorang yang dialami setelah membandingkan antara persepsi kinerja atau hasil suatu produk dengan harapan-harapannya. Kepuasan merupakan fungsi dari kesan sebuah kinerja dan harapan, jika kinerja dibawah harapan, maka pengguna atau nasabah akan merasa sangat puas. Menurut Zeithalm (1988) dalam Kotler (2009) disebutkan bahwa ada lima faktor yang mempengaruhi kepuasan konsumen, sebagai berikut.

(a). Kemudahan, yaitu tingkat dimana seseorang percaya bahwa dengan menggunakan sistem tertentu akan bebas dari kesalahan dan mudah untuk digunakan. Dalam faktor kemudahan terdapat beberapa indikator yang mengikuti, diantaranya: (1) pengoprasian transaksi mudah, (2) praktis dalam penggunaan, (3) layanan merchant memuaskan, dan (4) jaringan merchant yang luas, (b). Manfaat, yaitu tingkat dimana seseorang percaya bahwa dengan menggunakan suatu teknologi tertentu akan bermanfaat bagi seseorang, dimana dalam faktor manfaat terdapat beberapa indikator yang mengikuti, diantaranya: (1) mempercepat proses pembayaran, (2) meningkatkan ketelitian proses, (3) merasa lebih nyaman, dan (4) lebih efisien, (c). Risiko, yaitu keyakinan pengguna tentang kemungkinan dan kerugian yang dialami oleh pengguna, dalam faktor risiko terdapat beberapa indikator yang mengikuti, diantaranya: (1) potensi gagal melakukan pembayaran, (2) potensi kerugian karena kehilangan kartu, dan (3) sistem keamanan kartu, (d). Kepercayaan, yaitu kemauan seseorang untuk melakukan hubungan pertukaran dengan pihak lain atas dasar kepercayaan, dimana pada faktor kepercayaan terdapat beberapa indikator yang mengikuti, diantaranya: (1) kenyamanan transaksi dari vendor, (2) kepuasan terhadap vendor, dan (3) taggung jawab vendor, (e). Kualitas produk, yaitu keseluruhan barang dan jasa yang berkaitan dengan keinginan pengguna yang secara keunggulan produk sudah layak digunakan sesuai harapan dari pengguna, dimana pada faktor kualitas produk terdapat beberapa indikator yang mengikuti, diantaranya: (1) kinerja produk, (2) fitur produk, (3) daya tahan produk, dan (4) kesesuaian produk.

Suatu pelayanan yang dapat memuaskan penggunanya, jika sistem dari produk sudah dilakukan inovasi sesuai dengan perkembangan dunia modern sekarang maka kepuasan pengguna sendiri akan terpenuhi maka itu menjadi keberhasilan bagi bank dalam memberikan kepuasan penggunanya dan akan membuat pengguna loyal, pada akhirnya bisa memberikan pendapat yang baik bagi bank sendiri dalam kemajuan produk-produk barunya (Kotler, 2000). Salah satu faktor menentukan kepuasan pengguna adalah kemudahan menggunakan produk yang 
berfokus pada tidak menyulitkan pengguna saat melakukan transaksi (Zeithalm, 1988 dalam Kotler, 2009).

Perbankan kemudian tertarik untuk melakukan terobosan baru untuk meningkatkan kepuasan penggunanya terhadap produk dan jasa sesuai dengan perkembangan era modern dan kebutuhan masyarakat yang beragam, maka diciptakanlah bentuk lain dari uang tersebut yaitu dengan sistem pembayaran nontunai atau uang elektronik yang menggunakan kartu sebagai alat transaksinya.

Uang elektronik sendiri adalah sebuah alat pembayaran elektronik yang diperoleh dengan menyetorkan uang terlebih dahulu kepada penerbit, baik secara langsung maupun melalui agenagen penerbit dan nilai uang tersebut dimasukkan menjadi nilai uang dalam media elektronik yang digunakan sebagai alat pembayaran oleh pemegang kartu kepada pedagang. Uang elektronik pada dasarnya sama seperti uang karena memiliki fungsi sebagai alat pembayaran atas transaksi jual-beli barang (Peraturan Bank Indonesia Nomor 11/12/PBI/2009).

Transaksi menggunakan uang elektronik memiliki banyak kelebihan antara lain: (1) praktis, yaitu cukup membawa kartu yang mempunyai nilai rupiah tertentu, (2) aman, tidak perlu membawa uang tunai, (3) mudah, karena hanya menempelkan kartu pada mesin Electronic Data Capture (EDC) untuk bertransaksi dan dapat digunakan untuk transaksi ritel dengan nilai kecil. Penggunaan uang elektronik dapat memberikan sejumlah keuntungan bagi para penggunanya.

Bagi masyarakat atau konsumen, hal itu semakin meminimalkan penggunaan uang kartal bernilai kecil, sehingga memudahkan untuk melakukan transaksi, tanpa harus menyediakan uang semacam itu di saku atau dompet. Sementara bagi para penyedia layanan, tidak lagi harus menyediakan uang kecil untuk kembalian dan proses transaksinya pun dapat dilakukan lebih cepat. Sedangkan, bagi Bank Indonesia sebagi otoritas yang bertanggung jawab dalam menyediakan uang kartal, tak lagi dibebani dengan upaya menyediakan uang kartal yang nilainya cukup besar.

Anantara Seminyak Resort-Bali adalah salah satu hotel berbintang di Bali yang terus melakukan terobosan bermanfaat bagi karyawannya dengan menjadikan kawasan hotel sebagai Less Cash Society (masyarakat pengguna uang nontunai). Uang elektronik yang dipromosikan oleh beberapa bank yang mengeluarkan produk electronic money, diantaranya $\mathrm{BRI}$ dengan nama produk BRIZZI, BCA dengan Flazz BCA dan Bank Mandiri dengan Gaz Card serta E-Toll. Anantara Seminyak Resort-Bali melakukan terobosan melalui kerjasama dengan BCA, yang diwujudkan dengan ditandatanganinya Memorandum of Understanding (MoU) dengan BCA pada tanggal 21 Agustus 2013 di Anantara Seminyak Resort-Bali. Lingkup kerjasama antara Anantara Seminyak Resort-Bali dan BCA adalah penggunaan teknologi Flazz Card sebagai kartu identitas dan juga sebagai alat transaksi berskala kecil. Kartu Flazz BCA menawarkan kecepatan, kemudahan, kepraktisan bertransaksi. Cepat, karena transaksi pembayaran diselesaikan dalam hitungan detik dengan proses kerja contacless (tidak perlu digesek seperti kartu kredit, cukup diletakan di mesin reader). Mudah, karena tidak perlu menginput PIN (Personal Identification Number). Praktis, karena tidak perlu membawa uang tunai dalam jumlah besar, juga tidak perlu menyimpan uang receh lagi. Selain itu murah, karena tanpa biaya transaksi. Keuntungan lain, terhindar dari risiko kesalahan hitung dan uang palsu karena tidak terjadi transaksi tunai. Kemudahan bagi merchant, tidak perlu menyediakan uang kembalian, mempercepat layanan karena tidak perlu mengecek keaslian uang dan menghitung uang saat transaksi, dan juga tidak perlu menyimpan uang dalam jumlah besar. Kartu Flazz BCA ini adalah electronic purse atau dompet elektronik yang praktis digunakan untuk melakukan pembayaran transaksi jumlah kecil yang berkisaran minimal Rp.20.000 dan maksimal Rp.1.000.000.

Sebagai data awal, saya mewawancarai 30 karyawan mengenai 
tingkat kepuasan karyawan menggunakan uang elektronik kartu Flazz BCA, disana saya memperoleh data bahwa pada saat pengenalan uang elektronik kartu Flazz BCA yang sudah disosialisasikan oleh pihak bank, akan tetapi berbeda dengan apa yang dirasakan oleh karyawan Anantara Seminyak Resort - Bali sebagai pengguna uang elektronik kartu Flazz BCA, dimana terdapat beberapa masalah yang dialami karyawan saat melakukan transaksi dan sebagian besar karyawan Anantara Seminyak Resort - Bali sudah tidak lagi menggunakan uang elektronikkartu Flazz BCA sebagai alat pembayaran, melainkan hanya digunakan sebagai kartu identitas saja. Adapun beberapa alasan karyawan sudah tidak lagi menggunakan uang elektronik kartu Flazz BCA sebagai alat pembayaran, yaitu: mereka masih lebih nyaman menggunakan uang tunai, pembayaran yang dilakukan oleh nasabah dua kali lipat, belum membutuhkan emoney, kasir menolak kartu, mesin yang tidak bisa digunakan, merasa tidak aman karena tidak menggunakan PIN sebagai pengamannya, sudah memiliki kartu debet yang fungsinya dianggap sama saja, dan takut hilang.

Berdasarkan permasalahan diatas, maka peneliti menulis penelitian dengan judul "Faktor-Faktor yang Mempengaruhi Tingkat Kepuasan Karyawan Dalam Menggunakan Uang Elektronik Kartu Flazz BCA Di Lingkungan Anantara Seminyak Resort - Bali".Dari latar belakang yang telah ditentukan, maka dapat dirumuskan masalah sebagai berikut. (1) Faktor-faktor apa saja yang berpengaruh terhadap tingkat kepuasan karyawan dalam menggunakan uang elektronik kartu Flazz BCA di lingkungan Anantara Seminyak Resort - Bali? (2) Faktor mana yang paling dominan berpengaruh terhadap tingkat kepuasan karyawan dalam menggunakan uang elektronik kartu Flazz BCA di lingkungan Anantara Seminyak Resort Bali?.

Meninjau dari permasalahan yang ada maka tujuan penelitian ini adalah, (a) untuk mengetahui Faktor-faktor yang berpengaruh terhadap tingkat kepuasan karyawan dalam menggunakan uang elektronik kartu Flazz BCA di lingkungan Anantara Seminyak Resort - Bali, (b) untuk mengetahui faktor dominan yang mempengaruhi tingkat kepuasan karyawan dalam menggunakan uang elektronik kartu Flazz BCA di lingkungan Anantara Seminyak Resort - Bali.

Manfaat dari penelitian ini yaitu, (1) manfaat praktis, (a) masukan bagi pihak Anantara Seminyak Resort - Bali diharapkan menjadi bahan acuan dalam melakukan inovasi-inovasi terbaru khususnya pada alat bertransaksi yang bermanfaat bagi seluruh karyawan Anantara Seminyak Resort - Bali. (2) Manfaat teoritis, Hasil penelitian ini diharapkan dapat memberikan manfaat dalam pengembangan ilmu ekonomi pada bidang sistem informasi manajemen khususnya teknologi dan informasi salah satunya mengenai uang elektronik sebagai alat pembayaran yang praktis dan efisien.

\section{METODE}

Penelitian ini merupakan jenis penelitian faktorial. Adapun faktor-faktor yang diduga mempengaruhi tingkat kepuasan karyawan dalam menggunakan uang elektronik kartu Flazz BCA di lingkungan Anantara Seminyak Resort-Bali adalah (1) faktor kemudahan, (2) faktor manfaat, (3) faktor risiko, (4) faktor kepercayaan, dan (5) faktor kualitas produk. Dari hasil penelitian ini diharapkan peneliti dapat mengetahui faktor-faktor yang mempengaruhi penggunaan uang elektronik kartu Flazz BCA dan faktor yang paling dominan mempengaruhi penggunaan uang elektronik kartu Flazz BCA.

Populasi pada penelitian ini adalah seluruh karyawan Anantara Seminyak Resort-Bali dengan jumlah sebanyak 380 karyawan. Menurut Sugiyono (2008:116) penentuan pengambilan sampel sebagai berikut.

Apabila kurang dari 100, lebih baik diambil semua hingga penelitiannya merupakan penelitian populasi. Jika jumlah lebih dari 100 dapat diambil antara 10-15\% atau $20-25 \%$ atau lebih tergantung sedikit banyaknya dari hal sebagai berikut. 
a. Kemampuan peneliti dilihat dari waktu, tenaga dan dana,

b. Sempit luasnya wilayah pengamatan dari setiap subjek, karena hal menyangkut banyak sedikitnya dana,

c. Besar kecilnya risiko yang ditanggung peneliti.

Jadi peneliti menentukan jumlah sampel yang diteliti dengan menggunakan rumus Slovin (Sugiyono, 2010), yaitu:

$$
n=\frac{\mathrm{N}}{1+\mathrm{Ne}^{2}}
$$

Keterangan.

$\mathrm{n}=$ Jumlah Sampel

$\mathrm{N}=$ Jumlah Populasi

$\mathrm{e}=$ batas toleransi kesalahan (error tolerance)

Dengan jumlah populasi sebanyak 380 responden dan batas toleransi error sebesar $5 \%$ maka jumlah sampel penelitian dapat dilihat melalui rumus.

$$
\mathrm{n}=\mathrm{N} /\left(1+\mathrm{Ne}^{2}\right)=380 /(1+380 \mathrm{x}
$$
$\left.0,05^{2}\right)=194,9$ (yang dibulatkan menjadi 195), jadi jumlah sampel yang digunakan yaitu sejumlah 195 responden.

Dalam pengambilan sampel, peneliti menggunakan teknik simple random sampling (Sugiyono, 2003). Alasan peneliti menggunakan teknik simple random sampling dikarenakan cara pengambilan sampel dari populasi dilakukan secara acak dengan tidak mempertimbangkan strata atau tingkatan dalam populasi dan juga populasi yang diteliti bersifat homogen.

Jenisnya, data yang digunakan dalam penelitian ini adalah data kuantitatif. Data kuantitatif dalam penelitian ini meliputi data kuesioner yang diberikan oleh peneliti kepada responden serta keteranganketerangan mengenai tingkat kepuasan karyawan dalam menggunakan uang elektronik kartu Flazz BCA di lingkungan Anantara Seminyak Resort - Bali. Sumber data yang digunakan dalam penelitian ini yaitu, (1) data primer, data yang didapat langsung dari responden, yang berupa jawaban dari kuisioner tentang tingkat kepuasan karyawan dalam menggunakan uang elektronik kartu Flazz BCA di lingkungan Anantara Seminyak Resort Bali.

Data tersebut langsung diambil dengan menyebar kuesioner ke seluruh karyawan yang digunakan sebagai responden penelitian, (2) data sekunder, data tentang jumlah karyawan yang berjumlah 380 orang dan jabatan yang dapat melengkapi data primer dan juga data mengenai fungsi kartu Flazz BCA beserta fungsinya. Analisis data yang digunakan penelitian ini adalah analisis faktor. pengujian hipotesis dilakukan dengan menggunakan Statistical Program Social Scence (SPSS) 16.0 for Windows dengan menggunakan factor analysis.

\section{HASIL DAN PEMBAHASAN Hasil}

Analisis faktor digunakan untuk menganalisis hipotesis penelitian dengan memasukkan semua total nilai dari masingmasing dimensi atau faktor terhadap total skor item dari masing-masing dimensi. Skor dari masing-masing dimensi terlebih dahulu ditransformasikan ke dalam data interval kemudian dilakukan penentuan matrik korelasi, penentuan jumlah faktor, membuat rotasi faktor, dan menentukan skor masingmasing faktor.

Pada hasil output Statistical Package for the Social Sciences (SPSS) 16.0 for Windows (Anti image Matrices), dapat diketahui faktor-faktor atau variabelvariabel yang layak digunakan dalam analisis faktor. Pada output SPSS (Anti image Matrices), terdapat kode "a" yang artinya tanda untuk Measure of Sampling Adequacy (MSA). Faktor yang layak digunakan dalam analisis adalah faktor yang memiliki nilai MSA $>0,50$. Apabila terdapat faktor yang memiliki nilai MSA < 0,50 , maka faktor tersebut dikeluarkan agar dapat dilakukan analisis faktor

Data yang berhasil dikumpulkan dari kuesioner yang disebarkan dan setelah diolah dengan SPSS 16.0 for Windows menunjukkan faktor-faktor yang mempengaruhi tingkat kepuasan karyawan dalam menggunakan uang elektronik kartu Flazz BCA di lingkungan Anantara Seminyak Resort - Bali dapat dijelaskan oleh persentase dari masing-masing faktor. 
Nilai total Variance Explained digunakan untuk mengetahui persentase dari lima faktor yang dianalisis. Hasil analisis faktor melalui SPSS menunjukkan persentase dari masing-masing faktor dapat dilihat pada Tabel 2 berikut.

Tabel 1. Total Variance Explained

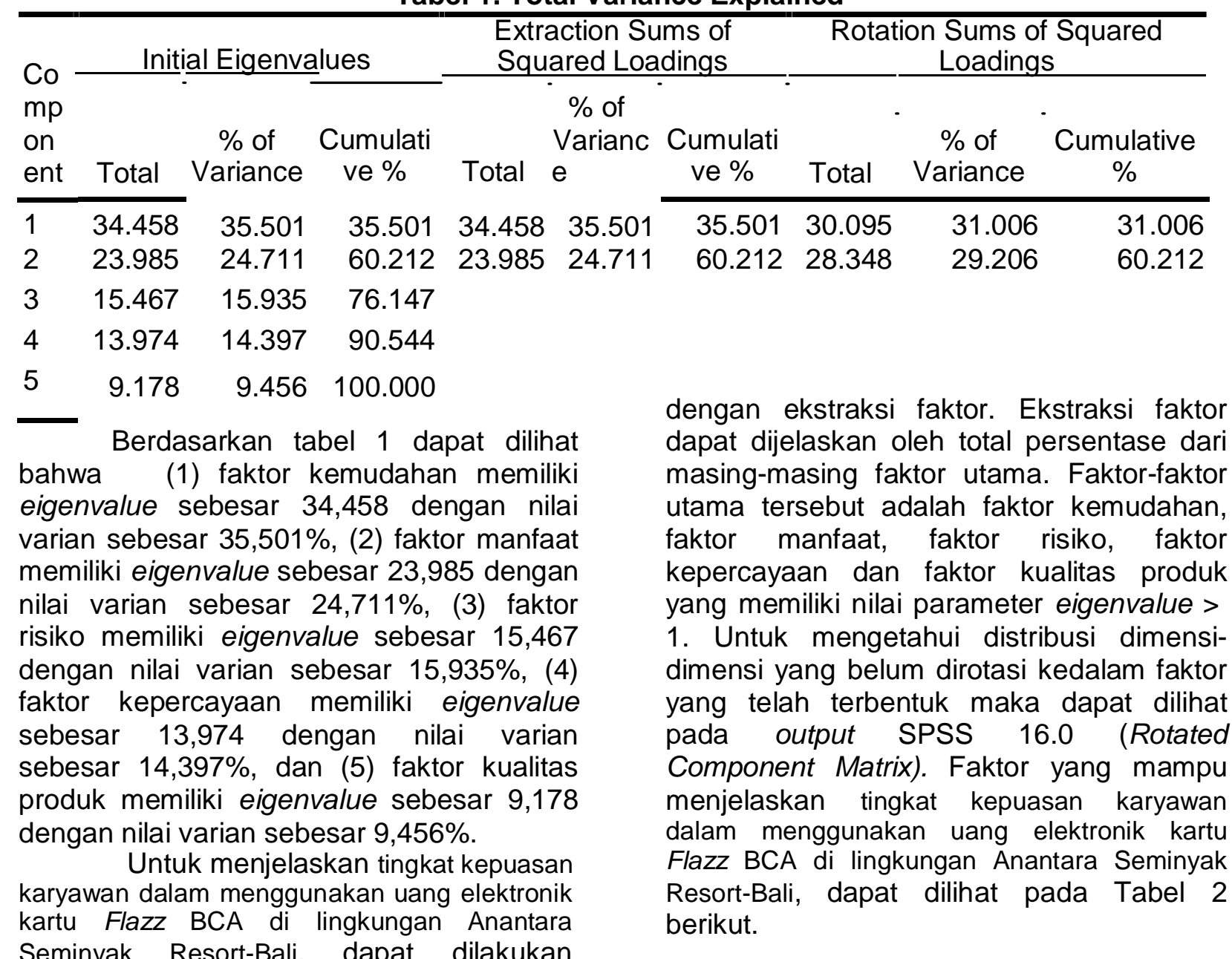

Seminyak Resort-Bali, dapat dilakukan

Tabel 2. Faktor yang menjelaskan tingkat kepuasan karyawan dalam menggunakan uang elektronik kartu Flazz BCA di lingkungan Anantara Seminyak Resort - Bali

\begin{tabular}{lccc}
\hline \multicolumn{1}{c}{ Faktor } & Eigenvalue & Varianced Explained (\%) & Faktor Loading \\
\hline Kemudahan & 34.458 & 35.501 & 5.236 \\
Manfaat & 23.985 & 24.711 & 4.463 \\
Risiko & 15.467 & 15.935 & 2.256 \\
Kepercayaan & 13.974 & 14.397 & 1.755 \\
Kualitas Produk & 9.178 & 9.456 & 1.329
\end{tabular}


memiliki eigenvalue $>1$ adalah faktor kemudahan, manfaat, risiko, kepercayaan dan kualitas produk, total nilai varianced explained dari kedua faktor keseluruhan mampu menjelaskan sebesar 97,058\%. Dengan demikian 97,058\% dari seluruh variabel yang ada, dapat dijelaskan oleh kelima faktor yang terbentuk. Kemudahan memiliki varianced explained 35,501\%, artinya bahwa faktor kemudahan mampu mempengaruhi tingkat kepuasan karyawan sebesar $35,501 \%$. Manfaat memiliki variance explained $24,711 \%$, artinya bahwa manfaat mempengaruhi tingkat kepuasan karyawan sebesar $24,711 \%$. Risiko memiliki variance explained $15,935 \%$, artinya bahwa risiko mempengaruhi tingkat kepuasan karyawan sebesar 15,935\%. Kepercayaan memiliki variance explained 14,397\%, artinya bahwa kepercayaan mempengaruhi tingkat kepuasan karyawan sebesar $14,397 \%$. Kualitas Produk memiliki variance explained $9,456 \%$, artinya bahwa kualitas produk mempengaruhi tingkat kepuasan karyawan sebesar $9,456 \%$.

Menentukan nama faktor yang telah terbentuk untuk masing-masing faktor bersifat subjektif, kadangkala variabel yang memiliki nilai faktor loading tertinggi digunakan untuk memberi nama faktor. Untuk melihat nilai faktor loading dapat dilihat pada Tabel 3 berikut.

Tabel 3. Rotated Component Matrix

\begin{tabular}{ccc}
\hline Faktor Kepuasan & \multicolumn{3}{c}{ Component } \\
\hline Manfaat & 1 & 2 \\
\hline Risiko & 4.463 & .549 \\
Kepercayaan & 2.256 & -.526 \\
\hline Kualitas Produk & 1.755 & .415 \\
Kemudahan & 1.329 & .433 \\
\hline
\end{tabular}

Bedasarkan Tabel 3 di atas, faktor yang mempengaruhi tingkat kepuasan karyawan dalam menggunakan uang elektronik kartu Flazz BCA di lingkungan Anantara Seminyak Resort - Bali adalah faktor kemudahan (X1) dengan faktor loading sebesar 5,236, faktor manfaat (X2) dengan faktor loading sebesar 4,463, faktor risiko (X3) dengan faktor loading sebesar 2,256, faktor kepercayaan (X4) dengan faktor loading sebesar 1,755 , dan faktor kualitas produk (X5) dengan faktor loading sebesar 1,329. Kemudian untuk menentukan dimensi atau faktor yang paling dominan mempengaruhi tingkat kepuasan karyawan dalam menggunakan uang elektronik kartu Flazz BCA di lingkungan Anantara Seminyak Resort - Bali, digunakan parameter koefisien varimax atau mendekati -1 . Nilai yang mendekati 1 diawali oleh nilai 0,50 sedangkan nilai yang mendekati -1 diawali oleh -0,50. Secara lebih rinci hasil ringkasan rotasi dari matriks faktor memuat nilai varimax rotation, dapat dilihat pada Tabel 4 berikut.

\section{Tabel 4. Matriks Rotasi Hasil Anallisis Faktor}

\begin{tabular}{clc}
\hline Dimensi atau faktor kepuasan karyawan & \multicolumn{2}{c}{ Varimax Rotation (\%) } \\
\cline { 2 - 3 } & $(1)$ & $(2)$ \\
\hline Kemudahan & 35,501 & - \\
Manfaat & - & 24,711 \\
\hline
\end{tabular}

Berdasarkan tabel 4 maka faktor yang paling dominan mempengaruhi tingkat kepuasan karyawan dalam menggunakan uang elektronik kartu Flazz BCA di lingkungan Anantara Seminyak Resort-Bali adalah faktor kemudahan dengan varimax 
rotation sebesar $35,501 \%$, dan manfaat dengan varimax rotation sebesar $24,711 \%$.

\section{Pembahasan}

Tingkat kepuasan karyawan dalam menggunakan uang elektronik kartu Flazz $B C A$ di lingkungan Anantara Seminyak Resort - Bali dipengaruhi oleh faktor kemudahan, manfaat, risiko, kepercayaan, dan kualitas produk. Hal ini sesuai dengan teori yang dinyatakan oleh Zeithalm (1988) dalam Kotler (2009), bahwa faktor yang mempengaruhi tingkat kepuasan karyawan dalam menggunakan uang elektronik kartu Flazz BCA di lingkungan Anantara Seminyak Resort - Bali adalah kemudahan dalam menggunakan, manfaat yang dirasakan, risiko yang dihadapi oleh pengguna, kepercayaan pada vendor, dan kualitas produk kartu Flazz BCA. Dengan demikian, untuk tingkat kepuasan karyawan dalam menggunakan uang elektronik kartu Flazz BCA di lingkungan Anantara Seminyak Resort - Bali, dapat dilihat dari faktor-faktor yang memiliki eigenvalue $>1$ yaitu, faktor kemudahan, faktor manfaat, faktor risiko, faktor kepercayaan, dan faktor kualitas produk.

Faktor kemudahan merupakan faktor yang paling dominan mempengaruhi tingkat kepuasan karyawan dalam menggunakan uang elektronik kartu Flazz BCA di lingkungan Anantara Seminyak Resort-Bali. Faktor ini paling dominan dibandingkan faktor-faktor yang lain yang disebabkan karena faktor kemudahan adalah faktor yang paling penting dalam penggunaan sebuah teknologi yang dirasa tidak perlu mengeluarkan tenaga atau usaha yang berlebihan untuk menggunakannya. Hasil penelitian ini sejalan dengan teori Zeithalm (1988) dalam Kotler (2009), faktor-faktor yang mempengaruhi tingkat kepuasan karyawan dalam menggunakan uang elektronik kartu Flazz BCA di lingkungan Anantara Seminyak Resort-Bali. Sedangkan pada hasil penelitian terdahulu dari Mohammad Nasrulloh (2007) dari enam faktor yang mempengaruhi kepuasan, hanya empat faktor yang mempengaruhi yaitu daya tahan produk, kesesuaian produk, kualitas produk dan kehandalan produk dan hasil dari penelitian terdahulu dari Teguh Wijaya Kusuma (2007) dari keenam faktor yang mempengaruhi kepuasan, hanya lima faktor yang mempengaruhi kepuasan.

\section{SIMPULAN DAN SARAN Simpulan}

Berdasarkan hasil analisis data dan pembahasan, maka dapat ditarik simpulan yaitu, (1) faktor-faktor yang mempengaruhi tingkat kepuasan karyawan dalam menggunakan uang elektronik kartu Flazz BCA di lingkungan Anantara Seminyak Resort - Bali adalah, (a) faktor kemudahan dengan nilai varian sebesar $35,501 \%$, (b) faktor manfaat dengan nilai varian sebesar $24,711 \%$, (c) faktor risiko dengan nilai varian $15,935 \%$, (d) faktor kepercayaan dengan nilai varian $14,397 \%$, (e) dan faktor kualitas produk dengan nilai varian $9,456 \%$.

(2) Faktor yang paling dominan mempengaruhi tingkat kepuasan karyawan dalam menggunakan uang elektronik kartu Flazz BCA di lingkungan Anantara Seminyak Resort - Bali adalah faktor kemudahan dengan nilai varimax rotation sebesar $35,501 \%$, dan faktor manfaat dengan nilai varimax rotation $24,711 \%$.

\section{Saran}

Berdasarkan pembahasan dan kesimpulan di atas, maka dapat diajukan beberapa saran yaitu, (1) bagi Anantara Seminyak Resort - Bali, diharapkan menjadi bahan acuan dalam melakukan inovasiinovasi teknologi terbaru khususnya alat bertransaksi yang bermanfaat bagi seluruh karyawan Anantara Seminyak Resort - Bali. (2) Bagi peneliti lain yang berminat untuk mendalami mengenai faktor-faktor yang mempengaruhi kepuasan karyawan dalam menggunakan uang elektronik diharapkan melakukan penelitian lebih lanjut. Hal ini berguna untuk membandingkan faktorfaktor yang mempengaruhi kepuasan karyawan dalam menggunakan uang elektronik yang berbeda dan ditempat yang berbeda pula.

\section{DAFTAR PUSTAKA}


Aaker D, A., Kumar, V., \& Day, G., Marketing Research $7^{\text {th }}$ edition, New Jersey, Jhon Wiley \& Sons. 2001.

Bank Central Asia. 2007. Kartu Flazz BCA. http://bca.co.id/kartu flazz bca. Diakses pada November 2016.

Bank Indonesia. 2009. Peraturan Bank Indonesia Nomor 11/12/PBI/2009, tentang Uang Elektronik. www.bi.go.id. Diakses pada tanggal 28 November 2016.

Bank for International Settlements (1996). Implication for Central Banks of the Development of Electronic Money, Basle, October, Page 1.

Bonugli P. K. 2006, "The Cashless Society: Increased Usage of Card-Based Payment System". Scholl of Electronic \& Computer Science, University of Southampton.

Barnes, James G. 2003: Secret of Consumer Relationship Management (Rahasia Manajemen Hubungan Pelanggan), Yogyakarta: ANDI.

Davis, F. D. 1989 "Perceived Usefulness, Perceived Ease of Use, and User Acceptance of Information Technology." MIS Quarterly, 13, pp. 319-339.

Davis, P. D., Bagozzi, R. P., danWarshaw, P. R. 1989, 'User Acceptance of Computer Technology: A Comparison of Two Theoritical Model's, dalamManagement Science, Vol. 35, No. 8, pp. 982-1003.

Fandy Tjiptono dan Anastasia Diana. 2003. Total Quality Management. Yogyakarta: Andi Offset.

2004. Manajemen Jasa. Yogyakarta: Andi Offset.

Fandy Tjiptono dan Gregorius Chandra. 2005. Service, Quality \& Satisfaction. Yogyakarta: Andi Offset.

Ghozali, Imam. 2011. Aplikasi Analisis
Multivariate dengan Program IMB SPSS 19. Edisi Kelima. Semarang: UniversitasDiponogoro.

Harbani Pasolong. 2010. Kepemimpinan Birokrasi. Bandung: CV Alfabeta

Husein, Umar. 2004. Metode Penelitian Untuk Skripsi dan Tesis Bisnis. Jakarta: Raja Grafindo Persada.

Istijanto, 2009. Aplikasi Praktis Riset Pemasaran: Cara Praktis Meneliti Konsumen dan Pesaing. Jakarta: PT. Gramedia Pustaka Indonesia.

Kasmir. 2000. Dasar-Dasar Perbankan. Jakarta: PT Raja Grafindo Persada.

Malhotra, N. K. 2007. Marketing Research: An Applied Orientation. Pearson Prentice Hall.

M. NurRianto al Arif. 2010. Dasar-Dasr Pemasaran Bank Syariah. Bandung: Alfabeta.

Nasrullah Mohammad. 2007. "Analisis Tingkat Kepuasan Konsumen Pada Produk Roti Arsila Bakrey Cabang Kapuas Kabupaten Kapuas Kalimantan Tengah", Jurnal Syariah dan Ekonomi Islam. Institut Agama Islam Nasional (IAIN) Antasari Banjarmasin.

Kotler Philip. 2000. Manajemen Pemasaran, (Terjemahan Jilid I), Edisi Milenium. Jakarta: PT Indeks Kelompok Gramedia.

Rangkuti. 2006. Measuring Costumer Satisfacation: Teknik Mengukur dan Strategi Meningkatkan Kepuasan Pelanggan. Jakarta: Gramedia Pustaka Utama.

Sarkiah. 2009. "Tingkat Kepuasan Nasabah Terhadap Produk Dana Tabungan Simpatik Bank Syariah KCP Kapuas Melalui Kerjasama Antar Sekolah", Jurnal Syariah dan Ekonomi Islam. Institut Agama Islam Nasional (IAIN) Antasari 
Sugiyono. 2010. Metode Penelitian Bisnis. Bandung: CV Alfabeta.

2010. Metode Kualitatif Kuantitatif dan $R$ \& $D$, Cetakan Keempat. Bandung: Alfabeta.

Suliyanto. 2005. Analisis Data dalam Aplikasi Pemasaran Bogor. Ghalia Indonesia.

Sunyoto, Danang. 2013. Teori Kuesioner dan Analisis Data. Yogyakarta: Grahal Imu.

Teguh Wijaya Kusuma 2010. "Perbandingan Tingkat Kepuasan Nasabah Terhadap Pelayanan Costumer Service Antar PT Bank Muamalat Indonesia Cabang Banjarmasin dan Bank Kalsel Syariah Banjarmasin", Jurnal Syariah dan Ekonomi Islam. Institut Agama Islam Nasional (IAIN) Antasari Banjarmasin.

Wikipedia 2009. Uang Elektronik. http://id.wikipedia.org/wiki/uang elektr onik. Diakses pada November 2016.

Zeithaml, Kotler. Service Marketing. McGraw Hill Inc, Int'l Edition, New York, 2009, p.162.

Zeithaml, Valarie A. and Bitner, Mary Jo. Service Marketing. McGraw Hill Inc, Int'l Edition, New York, 2003, p.85

Zeithalm, V. A., L. L. Berry and A. Parasuraman. 1996. "The Behavioral Consepuences of Service Quality". Journal of Marketing 1996, p31-46. 